\title{
Analysis of gas exchange in seedlings of Acer saccharum : integration of field and laboratory studies
}

\author{
J.A. Weber, T.W. Jurik, J.D. Tenhunen *, and D.M. Gates \\ Biological Station and Botanical Gardens, University of Michigan, Ann Arbor, MI 48109-1048, USA
}

\begin{abstract}
In the field, photosynthesis of Acer saccharum seedlings was rarely light saturated, even though light saturation occurs at about $100 \mu \mathrm{mol}$ quanta $\mathrm{m}^{-2} \mathrm{~s}^{-1}$ photosynthetic photon flux density (PPFD). PPFD during more than $75 \%$ of the daylight period was $50 \mu \mathrm{mol} \mathrm{m} \mathrm{m}^{-2} \mathrm{~s}^{-1}$ or less. At these low PPFD's there is a marked interaction of PPFD with the initial slope $(\mathrm{CE})$ of the $\mathrm{CO}_{2}$ response. At PPFDsaturation $C E$ was $0.018 \mu \mathrm{mol} \mathrm{m} \mathrm{m}^{-2} \mathrm{~s}^{-1} /(\mu 1 / 1)$. The apparent quantum efficiency (incident PPFD) at saturating $\mathrm{CO}_{2}$ was 0.05-0.08 mol $/ \mathrm{mol}$. $\mathrm{CO}_{2^{-}}$and PPFD-saturated $\mathrm{CO}_{2}$ exchange was $6-8 \mu \mathrm{mol} \mathrm{m}^{-2} \mathrm{~s}^{-1}$. The ratio of internal $\mathrm{CO}_{2}$ concentration to external $\left(C_{i} / C_{a}\right)$ was 0.7 to 0.8 except during sunflecks when it decreased to 0.5 . The decrease in $C_{i} / C_{a}$ during sunflecks was the result of the slow response of stomates to increased PPFD compared to the response of net photosynthesis. An empirical model, which included the above parameters was used to simulate the measured $\mathrm{CO}_{2}$
\end{abstract}

* Present address: Lehrstuhl für Botanik II der Universität Würzburg, Würzburg, Federal Republic of Germany

Offprint requests to: J.A. Weber

\section{List of symbols}

A: measured photosynthetic rate under any set of conditions $\left(\mu \mathrm{mol} \mathrm{m} \mathrm{m}^{-2} \mathrm{~s}^{-1}\right) ; A_{m}(\mathrm{~atm})$ : measured photosynthetic rate at saturating PPFD, $350 \mu \mathrm{l} / 1 \mathrm{CO}_{2}$ and $21 \%(\mathrm{v} / \mathrm{v}) \mathrm{O}_{2}\left(\mu \mathrm{mol} \mathrm{m} \mathrm{m}^{-2} \mathrm{~s}^{-1}\right)$; $C$ : constant in equation of Smith $(1937,1938) ; C_{a}: \mathrm{CO}_{2}$ concentration in the air $(\mu 1 / 1) ; C_{i}: \mathrm{CO}_{2}$ concentration in the intercellular air space $(\mu 1 / 1) ; C_{i}^{*}: C_{i}$ corrected for $\mathrm{CO}_{2}$ compensation point, i.e., $C_{i}-\Gamma^{*},(\mu 1 / 1) ; \mathrm{CE}$ : initial slope of the $\mathrm{CO}_{2}$ response of photosynthesis $\left(\mu \mathrm{mol} \mathrm{m}{ }^{-2} \mathrm{~s}^{-1} /(\mu 1 / 1)\right)$; CEM: CE at PPFD saturation; $E$ : transpiration rate $\left(\mathrm{mmol} \mathrm{m}^{-2} \mathrm{~s}^{-1}\right) ; F$ : predicted photosynthetic rate $\left(\mu \mathrm{mol} \mathrm{m} \mathrm{m}^{-2} \mathrm{~s}^{-1}\right) ; G$ : leaf conductance to $\mathrm{H}_{2} \mathrm{O}\left(\mathrm{mol} \mathrm{m}^{-2} \mathrm{~s}^{-1}\right)$; $I$ : photosynthetic photon flux density $\left(\mu \mathrm{mol} \mathrm{m} \mathrm{m}^{-2} \mathrm{~s}^{-1}\right) ; N$ : number of data points; $P_{m}$ : predicted photosynthetic rate at saturating $\mathrm{CO}_{2}$ and given PPFD $\left(\mu \mathrm{mol} \mathrm{m} \mathrm{m}^{-2} \mathrm{~s}^{-1}\right) ; P_{\mathrm{ml}}$ : predicted photosynthetic rate at saturating $\mathrm{CO}_{2}$ and $\operatorname{PPFD}\left(\mu \mathrm{mol} \mathrm{m} \mathrm{m}^{-2} \mathrm{~s}^{-1}\right) ; R_{d}$ : residual respiratory rate $\left(\mu \mathrm{mol} \mathrm{m}{ }^{-2} \mathrm{~s}^{-1}\right) ; T_{a}$ : air temperature $\left({ }^{\circ} \mathrm{C}\right)$; $T_{1}$ : leaf temperature $\left({ }^{\circ} \mathrm{C}\right) ; V$ : reaction velocity in equation of Smith $(1937,1938) ; V_{\max }:$ saturated reaction velocity in equation of Smith $(1937,1938)$; VPA: vapor pressure of water in the air (mbar/bar); VPD: vapor pressure difference between leaf and air (mbar/bar); $X$ : substrate concentration in equation of Smith $(1937,1938) ; \alpha$ : initial slope of the PPFD response of photosynthesis at saturating $\mathrm{CO}_{2}$ (mol CO$/ \mathrm{mol}$ quanta); $\alpha(\mathrm{atm})$ : initial slope of the PPFD response of photosynthesis at $340 \mu \mathrm{l} / 1 \mathrm{CO}_{2}$ and $21 \%(\mathrm{v} / \mathrm{v}) \mathrm{O}_{2}$ (mol $\mathrm{CO}_{2} /$ mol quanta); $\Gamma^{*}: \mathrm{CO}_{2}$ compensation point after correction for residual respiration $(\mu \mathrm{l} / 1) ; A$ : PPFD compensation point $(\mu \mathrm{mol}$ $\mathrm{m}^{-2} \mathrm{~s}^{-1}$ ) exchange rate for portions of two days. Parameter values for the model were determined in experiments separate from the daily time courses being sumulated. Analysis of the field data, partly through the use of simulations, indicate that the elimination of sunflecks would reduce net carbon gain by $5-10 \%$.

On the forest floor, light intensity, measured as photosynthetic photon flux density (PPFD), often remains below saturating values for net photosynthesis (Malkina et al. 1970; Pearcy 1983), in spite of adaptation of understory plants to low PPFD. Shade adapted leaves exhibit very efficient light utilization, low maximum photosynthetic and respiratory rates per unit area, and low light compensation points (Björkman 1968; Björkman, Ludlow and Morrow 1972; Boardman 1977; Larcher 1980; Pearcy and Calkin 1983). In an extremely dense rainforest of Queensland, Australia, Björkman et al. (1972) observed positive $\mathrm{CO}_{2}$ exchange rates in Alocasia macrorrhiza at PPFD below $10 \mu \mathrm{mol} \mathrm{m} \mathrm{m}^{-2} \mathrm{~s}^{-1}$. Pearcy and Calkin (1983) found a similar response in Claoxylon sandwicense growing in an Hawaiian rainforest. The low photosynthetic capacities of shadeadapted species as measured at PPFD-saturation appear to be genetically fixed and do not change markedly with variation in PPFD during growth (Logan and Krotkov 1968; Leverenz and Jarvis 1980; McMillan and McClendon 1983). While studies such as those of Björkman et al. (1972) and Pearcy and Calkin (1983) have demonstrated daily variation in $\mathrm{CO}_{2}$ exchange of understory species, these studies concentrated on the extreme shade habitats found in rainforests. Little is known about the daily time course response of understory woody plants in cold temperate deciduous forests. Existing data on photosynthesis of leaves of seedlings and saplings of shade-adapted, late successional species are mostly limited to studies in the laboratory, greenhouse, and nursery (Leverenz and Jarvis 1980; Logan and Krotkov 1968; Ledig and Korbobo 1983; McMillan and McClendon 1983) or to understory herbs (Young and Smith 1983).

In nature, seedlings of Acer saccharum grow in a low light environment characterized by relatively mild, constant conditions and moist, fertile soils with undisturbed litter. Leaves of these plants experience low PPFD except for brief periods when sunflecks fall on them (Spurr and Barnes 1980; Curtis 1959). The success of sugar maple in achieving 
dominance in later stages of forest development depends in part on its ability to survive under low light conditions until an opening in the canopy occurs. Demographic studies have shown that the seedlings may survive for a decade or more exhibiting only very slow growth (Hett and Loucks 1971). That $A$. saccharum is a shade species is demonstrated by the very limited ability of this species to acclimate to high light intensity (Logan and Krotkov 1968; McMillan and McClendon 1983).

In the present study we have analyzed the photosynthetic response of $A$. saccharum seedlings to variation in environmental conditions using both laboratory and field data. We assume that long term survival in nature is associated with a slightly positive carbon balance and that slow accumulation of carbon adequately provides for respiratory maintenance during the winter, reestablishment of the foliage during spring, and a small increment of growth of stems and roots. We have determined the total daily carbon gain per unit leaf area on typical days and extrapolated this daily gain to the growing season, fully recognizing the difficulties in such a projection. We have also investigated the importance of sunflecks to total carbon gain. Finally, we have examined the utility of simulating daily time course of net photosynthesis with a simple model of net photosynthetic response. The model allows us to study more fully the effect of a particular photosynthetic capacity, PPFD utilization efficiency, and stomatal behavior on primary production of maple seedlings growing in their natural habitat.

\section{Materials and methods}

\section{Field experiments}

In situ measurements of gas exchange were made on mature leaves of $A$. saccharum seedlings growing in a natural mixed hardwood forest at the University of Michigan Biological Station (Pellston, Michigan, USA) within $100 \mathrm{~m}$ of Douglas Lake. The soil is sandy (Rubicon sand, U.S. Soil Survey) with a moderately rich layer of humus in the A horizon. The seedlings were about 10 years old as estimated from budscale scars, but no more than $40 \mathrm{~cm}$ tall. Data obtained on 12 and 13 September, 1981 are representative of results obtained during the summer of 1981 and are analyzed in detail in the results section. For these experiments the leaf was inserted into the gas exchange cuvette on the evening before the measurements. Between 1 and 11 September, $3.45 \mathrm{~cm}$ of rain fell including $1.6 \mathrm{~cm}$ on 7 September. Temperatures were measured in a standard meteorological enclosure about $0.25 \mathrm{~km}$ distant from the study site. Average maximum temperature for the preceding month was $25^{\circ} \mathrm{C}$ with a high extreme of $28^{\circ} \mathrm{C}$; average minimum, $14^{\circ} \mathrm{C}$, with a low extreme of $10^{\circ} \mathrm{C}$. Maximum air temperatures on the forest floor tended to be a few degrees less than those measured in the meteorological enclosure.

Measurements of gas exchange were made using an open flow gas exchange system (Walz, Effeltrich, FRG), (Lange et al. 1967; Koch et al. 1971; Jurik et al. 1984). The leaf chamber was made of plexiglass the interior surfaces of which were covered with Teflon film (du Pont S-115) to reduce water vapor absorption. Volume of the chamber was 61 . Flow rate through the chamber was $1-21 / \mathrm{min}$. During the measurement of the diurnal time courses the air temperature inside the leaf chamber was controlled to be equal to air temperature at a position similar to that of the leaf being measured. Air for the system was collected $7 \mathrm{~m}$ above-ground and $15 \mathrm{~m}$ upwind of the experimental site and was pumped through a $0.1 \mathrm{~m}^{3}$ buffer box before entering the system. Carbon dioxide and water vapor concentrations of the incoming air were not controlled.

\section{Laboratory experiments}

Five to ten-year old seedlings were collected in May 1982 from a site north of Douglas Lake. They were brought to the University of Michigan Matthaei Botanical Gardens where they were potted in $15 \mathrm{~cm}$ diameter pots with $2,500 \mathrm{~cm}^{3}$ of soil (peat:leaf mold: perlite:vermiculite:sand, $4: 2: 1: 1: 2)$ and fertilized with a $12: 12: 12(\% \mathrm{~N}: \mathrm{P}: \mathrm{K})$ fertilizer. After potting, the seedlings were placed outside under three layers of greenhouse shade cloth to simulate light conditions on the forest floor. PPFD, measured with a quantum sensor (LI-190S, LICOR, Lincoln, Nebraska, USA), was approximately $10 \%$ of that in the open at midday, about 2 times that measured in the natural habitat during periods without sunflecks. Plants were watered regularly to avoid water stress. A wide range of gas mixtures (experimental gas) was produced using 4 Wösthoff (Bochum, FGR) gas mixing pumps in series and pure $\mathrm{CO}_{2}$, $\mathrm{O}_{2}$, and $\mathrm{N}_{2}$. A portion of the mixed gas was used as a reference for the differential infrared gas analyzer (Sensors, Ann Arbor, Michigan, USA). Gas entering the gas analyzer (IRGA) was dried with $\mathrm{Mg}\left(\mathrm{ClO}_{4}\right)_{2}$. The IRGA was calibrated for each $\mathrm{CO}_{2}$ concentration during each experiment by measuring a zero differential, i.e., experimental gas on both sides of the IRGA, and a gas of known differential (span gas) from the experimental gas. The span gas was produced by diluting a portion of the experimental gas by $1-10 \%$ with nitrogen using a gas mixing pump (Wösthoff). The slope of the line connecting the zero and span readings was used to calculate the differential in $\mathrm{CO}_{2}$ concentration across the leaf chamber. To the extent possible, the $\mathrm{CO}_{2}$ in the span gas was adjusted to be near the concentration of $\mathrm{CO}_{2}$ in the gas exiting the leaf chamber. The remaining gas was humidified by passing it through a sparging bottle. The dew point of the gas entering the leaf chamber was set in a temperature conditioning column. Flow rates to the leaf chamber, reference side of the gas analyzer, and the upscale reference pump were controlled with flow controllers (Condyne, Pasedena, California, USA). Excess gas was vented through a pressure control valve which maintained pressure upstream of the flow controllers at $50 \mathrm{kPa}$. Flow rate into the leaf chamber, after humidification, was measured with a mass flow meter (Teledyne Hastings-Raydist, Hampton, Virginia, USA). The lucite leaf chamber was $14 \mathrm{~cm}$ in diameter and $5 \mathrm{~cm}$ deep with an anodized aluminum plate on the bottom to aid in heat exchange. Except for the aluminum, the walls of the chamber were covered with a Teflon film (du Pont S-115) to reduce adsorption of water (Bloom et al. 1981). Leaf temperature was controlled to $\pm 0.1^{\circ} \mathrm{C}$ with a water jacket above and below the leaf chamber. Temperature of the water jacket was controlled using an electronic temperature controller which directed water through solenoids to constant temperature hot and cold baths. Concentration of $\mathrm{CO}_{2}$ in the leaf chamber was corrected for dilution by transpired water vapor. Carbon dioxide concentration inside the leaf was calculated according to the equation of Wong et al. (1980). Rates are expressed on a projected leaf area basis. 


\section{Net photosynthesis model}

The response of photosynthesis (A) to increasing $\mathrm{CO}_{2}$ or PPFD level has three phases: 1) an initial nearly linear increase with $\mathrm{CO}_{2}$ concentration or PPFD, 2) a transition zone, and 3) $\mathrm{CO}_{2}$ or PPFD saturated region. Smith (1937, 1938) noted that the transition occurs more rapidly than would be expected for simple Michaelis-Menten kinetics. $\mathrm{He}$ proposed an empirical equation for light and $\mathrm{CO}_{2}$ responses which has the property of being nearly linear through the limited phase then rapidly reaching a plateau:

$V=\frac{C \cdot V_{\max } \cdot X}{\left(V_{\max }^{2}+C^{2} \cdot X^{2}\right)^{1 / 2}}$,

where: $V_{\max }$ is saturated rate of reaction for substrate $X$; $V$ is the exhibited rate of reaction; $X$ is substrate concentration; and $C$ is a constant.

Tenhunen et al. (1976) used a rearrangement of Eq. (1) to describe the $\mathrm{CO}_{2}$-saturated light response of photosynthesis:

$P_{\mathrm{m}}=\frac{\alpha \cdot I \cdot P_{\mathrm{ml}}}{\left(P_{\mathrm{m} l}^{2}+\alpha^{2} \cdot I^{2}\right)^{1 / 2}}$,

where: $P_{\mathrm{ml}}$ is the light and $\mathrm{CO}_{2}$-saturated rate of photosynthesis ( $\mu \mathrm{mol} \mathrm{m} \mathrm{m}^{-2} \mathrm{~s}^{-1}$ ); $\alpha$ is the initial slope of the light response ( $\mathrm{mol} \mathrm{CO} / \mathrm{mol}$ quanta); $I$ is PPFD ( $\mu \mathrm{mol}$ quanta $\left.\mathrm{m}^{-2} \mathrm{~s}^{-1}\right) ; P_{\mathrm{m}}$ is the $\mathrm{CO}_{2}$-saturated rate at a particular PPFD and given temperature ( $\left.\mu \mathrm{mol} \mathrm{m} \mathrm{m}^{-2} \mathrm{~s}^{-1}\right)$.

A similar equation can be used to describe the $\mathrm{CO}_{2}$ response:

$F=\frac{\mathrm{CE} \cdot C_{i}^{*} \cdot P_{m}}{\left(P_{m}^{2}+\mathrm{CE}^{2} \cdot C_{i}^{* 2}\right)^{1 / 2}}-R_{d}$,

where: $P_{m}$ is the $\mathrm{CO}_{2}$-saturated rate at a given PPFD ( $\mu \mathrm{mol}$ $\left.\mathrm{m}^{-2} \mathrm{~s}^{-1}\right)$; CE is initial slope of the $\mathrm{CO}_{2}$ response ( $\mu \mathrm{mol}$ $\left.\mathrm{m}^{-2} \mathrm{~s}^{-1}\right) ; C_{i}^{*}$ is the difference between $\mathrm{CO}_{2}$ concentration in the intercellular air space $\left(C_{i}\right)$ and $\Gamma^{*}(\mu 1 / 1) ; \Gamma^{*}$ is the $\mathrm{CO}_{2}$ compensation point at a given temperature as determined from the $\mathrm{CO}_{2}$ response which has been corrected for $R_{d}(\mu \mathrm{l} / \mathrm{l}) ; R_{d}$ is the axis correction needed to compensate for dark respiration ( $\mu \mathrm{mol} \mathrm{m} \mathrm{m}^{-2} \mathrm{~s}^{-1}$ ); and $F$ is the photosynthetic rate at a given temperature, $\mathrm{CO}_{2}$ concentration, and PPFD ( $\mu \mathrm{mol} \mathrm{m} \mathrm{m}^{-2} \mathrm{~s}^{-1}$ ).

In the present model we assume that $R_{d}$ is not affected by PPFD and represents the continued contribution of nonphotosynthetic (dark) respiration in the leaf. Subtraction of $R_{d}$ from measured assimilation rate, $A$, and of $\Gamma^{*}$ from $C_{i}$ are the only respiratory corrections in the model. By substituting Eq. (2) into Eq. (3) and rearranging, we obtain:

$F=\frac{\mathrm{CE} \cdot C_{i}^{*} \cdot \alpha \cdot P_{\mathrm{ml}}}{\left(\left(\alpha \cdot I \cdot P_{\mathrm{ml}}\right)^{2}+\left(\mathrm{CE} \cdot C_{i}^{*} \cdot P_{\mathrm{ml}}\right)^{2}+\left(\mathrm{CE} \cdot C_{i}^{*} \cdot \alpha \cdot I\right)^{2}\right)^{1 / 2}}-R_{d}$,

Temperature effects on the parameters, $P_{\mathrm{m} 1}, \alpha, \Gamma^{*}, \mathrm{CE}$, and $R_{d}$ can be included using either the Arrhenius equation or an equation by Johnson et al. (1954) (see descussion by Tenhunen et al. 1976). For our purposes the Arrhenius equation proved adequate.

\section{Parameter determination}

Model parameters were determined from response curves of net $\mathrm{CO}_{2}$ exchange by two methods. When data for a complete response curve were available, the parameters were estimated from a non-linear least squares fit using a program from the Biomedical Computer Programs package (BMDX85; Dixon 1969) to the appropriate equation after correction for dark respiration $\left(R_{d}\right)$. The $\mathrm{CO}_{2}$ response was also adjusted so that the response curve passed through the origin by subtracting $I^{*}$ from $C_{i}$. Each fit gave estimates of the initial slopes (CE or $\alpha$ ) and the PPFD- and $\mathrm{CO}_{2}$-saturated rate $\left(P_{\mathrm{m} 1}\right)$. The second method was employed for determination of the $\mathrm{CO}_{2}$ and PPFD compensation points ( $I^{*}$ and $A$ ) for data sets that had only data near saturation and near the compensation point. In this case a linear regression based on the lowest three points for the independent variable $\left(C_{i}\right.$ or PPFD) was used to estimate the initial slope and compensation point. Maximum rates were estimated at PPFD of $1,200 \mu \mathrm{mol} \mathrm{m} \mathrm{m}^{-2} \mathrm{~s}^{-1}$ or greater and at an external $\mathrm{CO}_{2}\left(C_{a}\right)$ of approximately $2,000 \mu \mathrm{l} / 1$ for $P_{\mathrm{ML}}$. Both methods gave similar results.

The diurnal course of $\mathrm{CO}_{2}$ exchange was simulated using Eq. (4) and the Arrhenius equation for the effect of temperature on $P_{\mathrm{ml}}$ and $R_{d}$ (see below). A linear equation was used for $\Gamma^{*}$. Parameters were estimated, as described above, from independent sets of field and laboratory data. Input variables for simulation of field responses were PPFD, chamber $\mathrm{CO}_{2}$, leaf temperature, and leaf conductance to water vapor.

\section{Results}

\section{Response curves}

In order to estimate the seasonal variability of photosynthesis in $A$. saccharum, several response curves of net photosynthesis to PPFD for plants in the natural habitat were measured throughout the growing season at concentrations of $\mathrm{CO}_{2}$ between 300 and $350 \mu \mathrm{l} / \mathrm{l}$ and $21 \% \mathrm{O}_{2}$. Under these conditions the apparent incident quantum efficiency, $\alpha(\mathrm{atm})$, and the PPFD-saturated photosynthetic rate, $A_{m}$ (atm), were determined as the initial slope and maximum of each response curve, respectively. It should be noted that $\alpha(\mathrm{atm})$ is less than $\alpha$ (Table 1) because the latter is measured under non-photorespiratory conditions whereas the former is not. For responses obtained between 20 and $25^{\circ} \mathrm{C}$, neither $\alpha(\mathrm{atm})$ nor $A_{m}$ (atm) changed significantly between the end of May, when the leaves had just completed expansion, and the end of the growing season in September (Table 1A). The decrease in the light compensation point $(A)$ was likely related to a decrease in respiration of the leaves. It seems that the production system in A. saccharum leaves is relatively stable for long periods allowing the application over most of the growing season of a photosynthetic model developed for such leaves. A similar situation was found for mature apricot leaves (Tenhunen et al. 1980).

The parameter values obtained from analysis of net photosynthetic response curves obtained in the field and in the laboratory are summarized in Table 1 . The maximum quantum efficiency $(\alpha)$ was determined as the initial slope of the response of $\mathrm{A}$ to incident PPFD under non-photorespiring conditions, i.e., at high $\mathrm{CO}_{2}$ concentration (Fig. 1, bottom). At $25^{\circ} \mathrm{C}$ the value obtained for $\alpha$ was $0.05-0.08 \mathrm{~mol} \mathrm{CO} / \mathrm{mol}$ quanta. From the response of $A$ to $C_{i}$ (Fig. 1, top) a value of $\mathrm{CE}$ (initial slope of the response) at $25^{\circ} \mathrm{C}$ of $0.019 \mu \mathrm{mol} \mathrm{m} \mathrm{m}^{-2} \mathrm{~s}^{-1} /(\mu \mathrm{l} / \mathrm{l})$ was found. The saturated rates of both response curves, which were 6.89 and $7.5 \mu \mathrm{mol} \mathrm{m} \mathrm{m}^{-2} \mathrm{~s}^{-1}$, respectively, provide estimates of $P_{\mathrm{m} 1}$ for $25^{\circ} \mathrm{C}$. 
Table 1. PPFD and $\mathrm{CO}_{2}$ response characteristics as determined in the field and in the laboratory. A. The initial slope $(\alpha(\mathrm{atm}))$, PPFD compensation point $(A)$, and PPFD-saturated rate at approximately $350 \mu \mathrm{l} / 1 \mathrm{CO}_{2}$ and $21 \% \mathrm{O}_{2}\left(\mathrm{~A}_{\mathrm{m}}(\mathrm{atm})\right)$. B. Initial slopes for $\mathrm{CO}_{2}(\mathrm{CE})$ response at saturating PPFD and for PPFD response $(\alpha)$ at saturating $\mathrm{CO}_{2}$ and the $\mathrm{CO}_{2}$ - and PPFD-saturated rate as measured at $25 \mathrm{C}$ and $21 \% \mathrm{O}_{2}$. C. Activation energies for $P_{\mathrm{ml}}$ and $R_{d}$

A. Field response, atmospheric gas concentrations, $20-25^{\circ} \mathrm{C}$

\begin{tabular}{lllll}
\hline Dates & $\begin{array}{l}\alpha(\mathrm{atm}) \\
\mathrm{mol} / \mathrm{mol}\end{array}$ & $\begin{array}{l}A_{m}(\mathrm{~atm}) \\
\mu \mathrm{mol} \mathrm{m}^{-2} \mathrm{~s}^{-1}\end{array}$ & $\begin{array}{l}A \\
\mu \mathrm{mol} \mathrm{m}^{-2} \mathrm{~s}^{-1}\end{array}$ \\
\hline 26-31 May & $0.038 \pm 0.002$ & $3.4 \pm 0.3$ & $6.8 \pm 1.7$ & 5 \\
1-24 June & $0.039 \pm 0.004$ & $3.5 \pm 0.7$ & $5.3 \pm 1.0$ & 6 \\
6 Aug.-17 Sep. $0.040 \pm 0.003$ & $3.8 \pm 0.5$ & $3.2 \pm 3.3$ & 5 \\
\hline
\end{tabular}

B. Response characteristics at $25^{\circ} \mathrm{C}$ and saturating $\mathrm{CO}_{2}$ and PPFD

\begin{tabular}{llll} 
& $\begin{array}{l}\mathrm{CE} \\
\mu \mathrm{mol} \mathrm{m}\end{array}$ & $\begin{array}{l}\alpha \\
\mathrm{mol} / \mathrm{mol}\end{array}$ & $\begin{array}{l}P_{\mathrm{m} 1} \\
\mu \mathrm{mol} \mathrm{m} \mathrm{m}^{-2} \mathrm{~s}^{-1}\end{array}$ \\
\hline Field & 0.018 & $0.05-0.08$ & $6.3-7.5$ \\
Laboratory & 0.018 & $0.06 \pm 0.01$ & $7.0-9.0$ \\
\hline
\end{tabular}

C. Temperature responses

\begin{tabular}{lll}
\hline Parameter & kJoule $/ \mathrm{mol}$ & Constant \\
\hline
\end{tabular}

Arrhenius equation

$\begin{array}{lll}P_{\text {ml }} & 28 & 13.02 \\ R_{d} & 42 & 14.76\end{array}$

$\mathrm{CO}_{2}$ Compensation point

$\Gamma^{*}=\left(4.0 * T_{1}+34.4\right) *$ Atm. Press $/\left(T_{1}+273.16\right)$
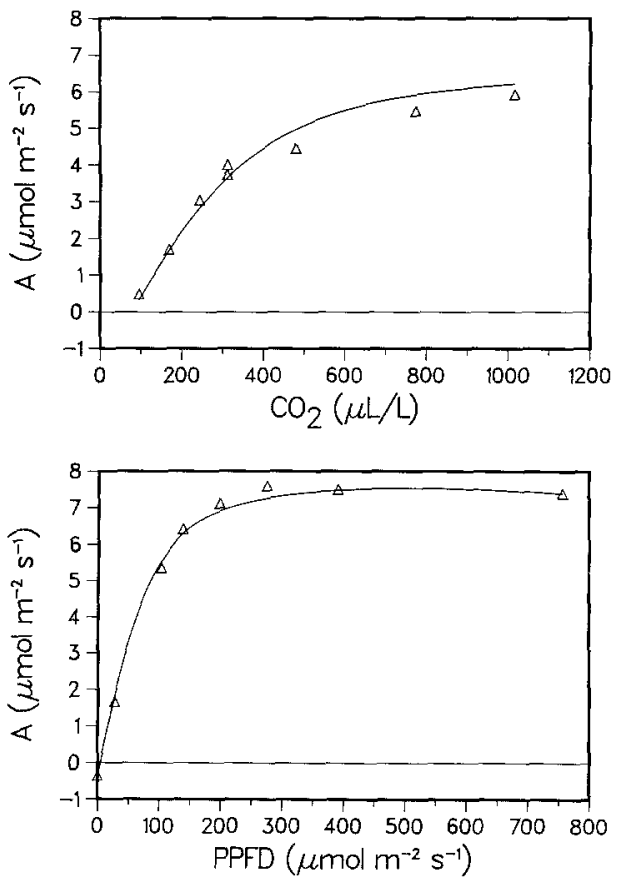

Fig. 1. Top. Photosynthetic response to $\mathrm{CO}_{2}$ at saturating $P P F D$ $\left(1,500 \mu \mathrm{mol} \mathrm{m}{ }^{-2} \mathrm{~s}^{-1}\right) . P_{\mathrm{ml}}=6.89 \mu \mathrm{mol} \mathrm{m}{ }^{-2} \mathrm{~s}^{-1} . \mathrm{CE}=0.019 \mu \mathrm{mol}$ $\mathrm{m}^{-2} \mathrm{~s}^{-1} /(\mu 1 / 1) . \quad \Gamma=66 \mu \mathrm{l} / 1$. Bottom. Photosynthetic response to $P P F D$ at saturating $\mathrm{CO}_{2}\left(C_{a} 2,000 \mu 1 / 1\right)$ and $25^{\circ}$ C. $P_{\mathrm{ml}}=7.5 \mu \mathrm{mol}$ $\mathrm{m}^{-2} \mathrm{~s}^{-1} . \quad \alpha=0.08 \mathrm{~mol} / \mathrm{mol} . R_{d}=0.35 \mu \mathrm{mol} \mathrm{m} \mathrm{m}^{-2} \mathrm{~s}^{-1}$. Measurements made in the field

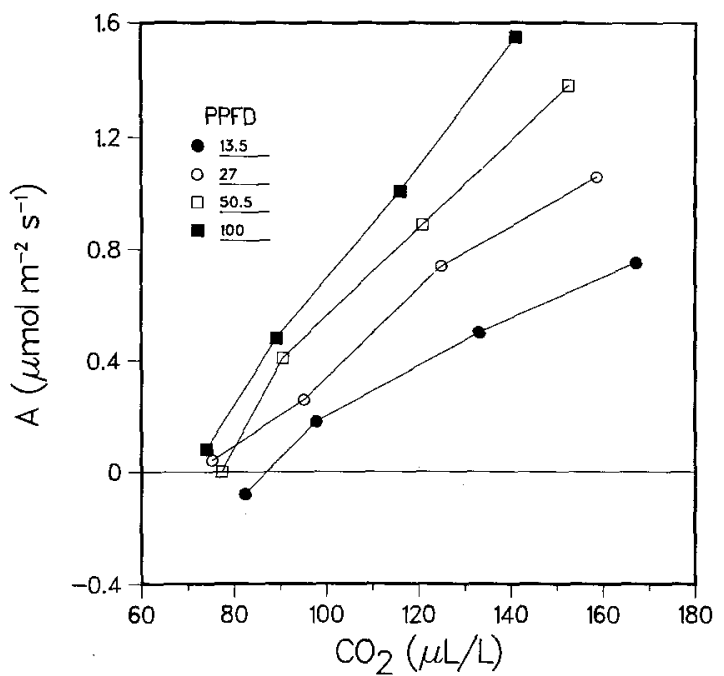

Fig. 2. The effect of variation of $P P F D$ on the initial slope of the $\mathrm{CO}_{2}$ response. $T_{1}: 25^{\circ} \mathrm{C}$. Laboratory data

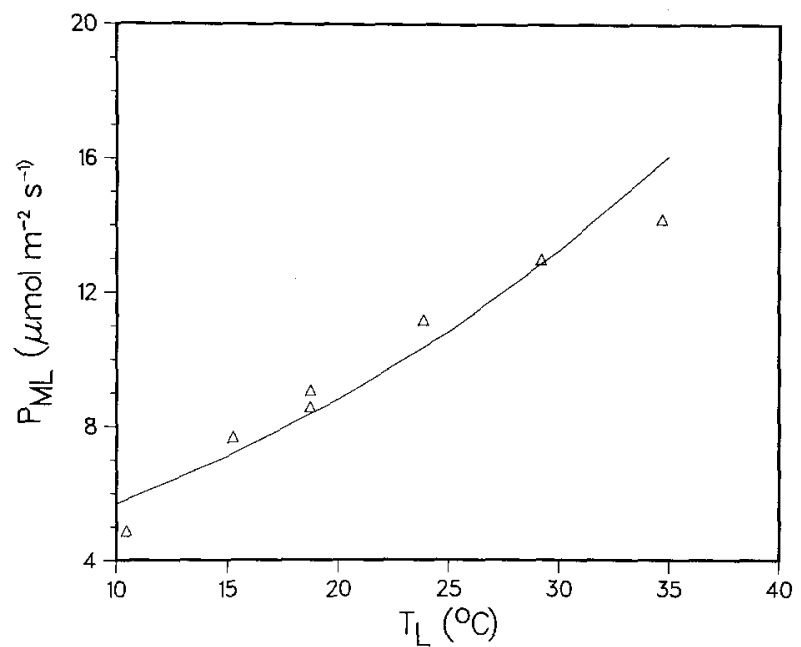

Fig. 3. The effect of leaf temperature $\left(T_{1}\right)$ on the $\mathrm{CO}_{2}$ - and PPFDsaturated photosynthetic rate $\left(P_{\mathrm{ml}}\right) . \quad C_{a}=1,900 \mu 1 / 1 . \quad \mathrm{PPFD}=$ $1,500 \mu \mathrm{mol} \mathrm{m} \mathrm{m}^{-2} \mathrm{~s}^{-1}$. Activation energy $=28 \mathrm{~kJ}$ oule $/ \mathrm{mol}$. Constant $=13.02$. Laboratory data

In order to clarify temperature dependencies of the parameters, detailed laboratory investigations were undertaken. In these experiments, the five parameters $-\alpha, \Gamma^{*}$, CE, $R_{d}$, and $P_{\mathrm{m} 1}$ - were determined for each replicate leaf. An average value for $\alpha$ of $0.058 \pm 0.0011 \mathrm{~mol} \mathrm{CO} / \mathrm{mol}$ quanta was obtained. The light compensation point $(A)$ was estimated as $3.4 \pm 1.6 \mu \mathrm{mol} \mathrm{m}^{-2} \mathrm{~s}^{-1}$. There was no detectable effect of temperature on either $\alpha$ or $A$ over the temperature range of interest.

Analysis of the response of net photosynthesis to $\mathrm{CO}_{2}$ concentration showed that $\mathrm{CE}$ was not significantly affected by temperature between 18 and $28^{\circ} \mathrm{C}$, the temperature range of interest in the natural habitat. We did find, however, that CE was affected by PPFD (Fig. 2) when determined between 80 and $160 \mu 1 / 1 C_{i}$. The decrease of the slope (CE) with decreasing PPFD is quite important because leaves of $A$. saccharum seedlings experience PPFD in the range which was found to influence $\mathrm{CE}$ during most of the day. The $\mathrm{CO}_{2}$ compensation point $\left(I^{*}\right)$ increased with temperature being $38 \mu \mathrm{l} / 1$ at $20^{\circ} \mathrm{C}$ and 44 at $25^{\circ} \mathrm{C}$. 

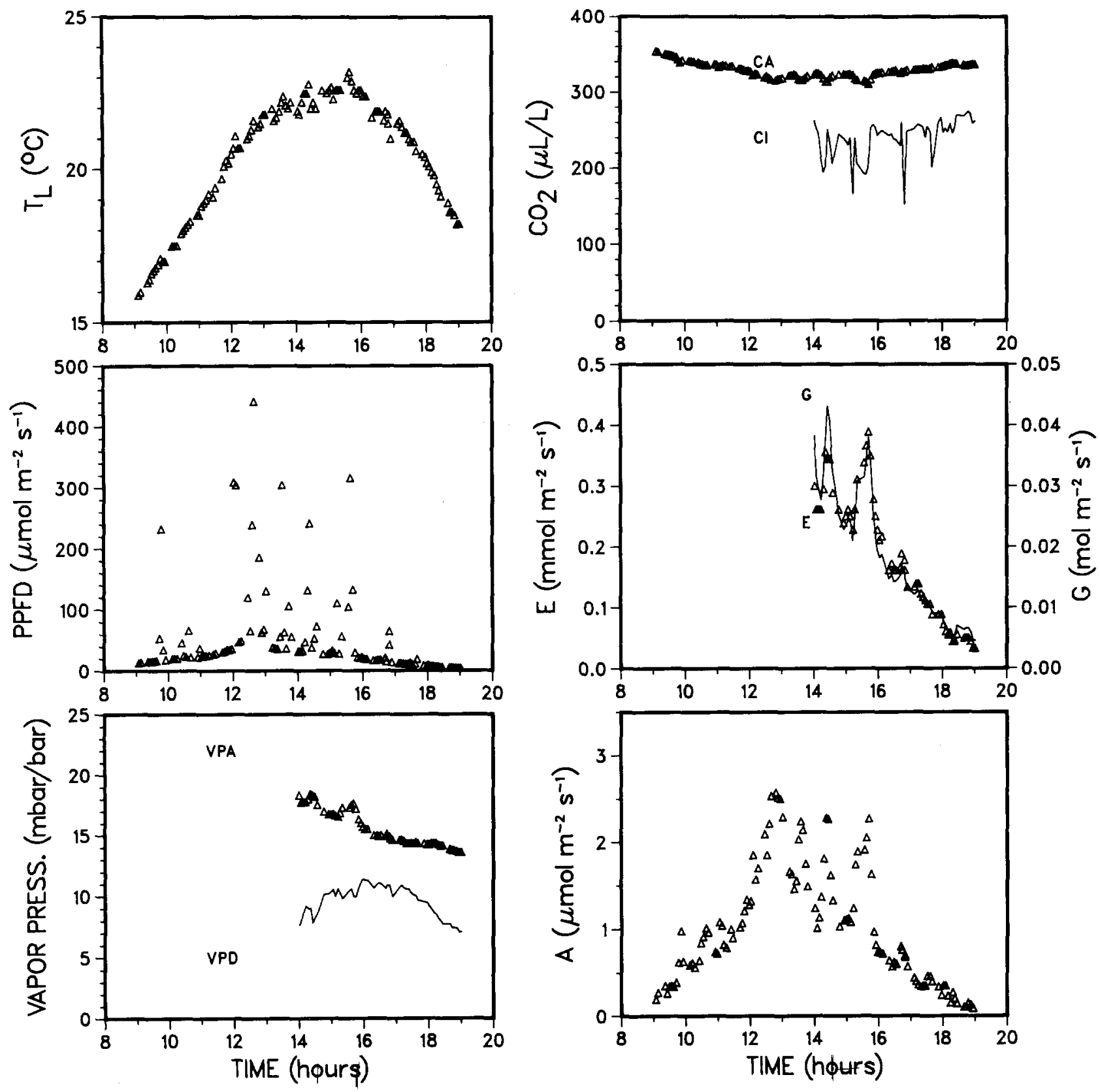

Fig. 4. Diurnal course of photosynthesis $A$, transpiration $E$, leaf conductance to water vapor $G$, and environmental factors for 12 Sept 1981. Condensation in the leaf chamber interfered with transpiration measurements until about 14:00

The rate of photosynthesis at saturating PPFD and $\mathrm{CO}_{2}$ concentration, $P_{\mathrm{ml}}$, was strongly affected by leaf temperature (Fig. 3). Since leaf temperatures measured in the natural habitat were below $25^{\circ} \mathrm{C}$ and, therefore below the temperature optimum for $P_{m l}$, the data were fit to the Arrhenius equation. The activation energy for $P_{\mathrm{ml}}$ was approximately $28 \mathrm{~kJ} / \mathrm{mol}$. Dark respiration, $R_{d}$, measured in the field measurements and in the laboratory was quite low. At $25^{\circ} \mathrm{C} R_{d}$ was approximately $0.2 \mu \mathrm{mol} \mathrm{m} \mathrm{m}^{-2} \mathrm{~s}^{-1}$. The activation energy was estimated at $42 \mathrm{~kJ} / \mathrm{mol}$.

\section{Time course of gas exchange in the field}

Time courses for PPFD, leaf temperature $\left(T_{1}\right)$, water vapor pressure in the air (VPA) and the vapor pressure difference between the leaf and air (VPD), $\mathrm{CO}_{2}$ pressure in the chamber $\left(C_{a}\right)$ and in the leaf $\left(C_{i}\right)$, transpiration rate $(E)$, net photosynthetic rate $(A)$, and leaf conductance to water vapor $(G)$ are shown in Figs. 4 and 5 for leaves of $A$. saccharum measured on 12 and 13 September 1981. It is apparent from the figures that of the environmental factors shown, PPFD shows the greatest variation, changing 5 to 10 fold within minutes. The peaks in PPFD occur as the solar beam reaches the forest floor through breaks in the canopy. Net photosynthetic rate is positively correlated with $T_{l}$, PPFD, VPA, and $\mathrm{G}$, but negatively correlated with $C_{a}$ (Table 2). The negative correlation of $A$ with $C_{a}$ is the result of a decrease in $\mathrm{CO}_{2}$ concentration in the incoming air during the middle of the day when $\mathrm{A}$ was the highest. Ignoring temperature and conductance effects on $\mathrm{A}$ and 

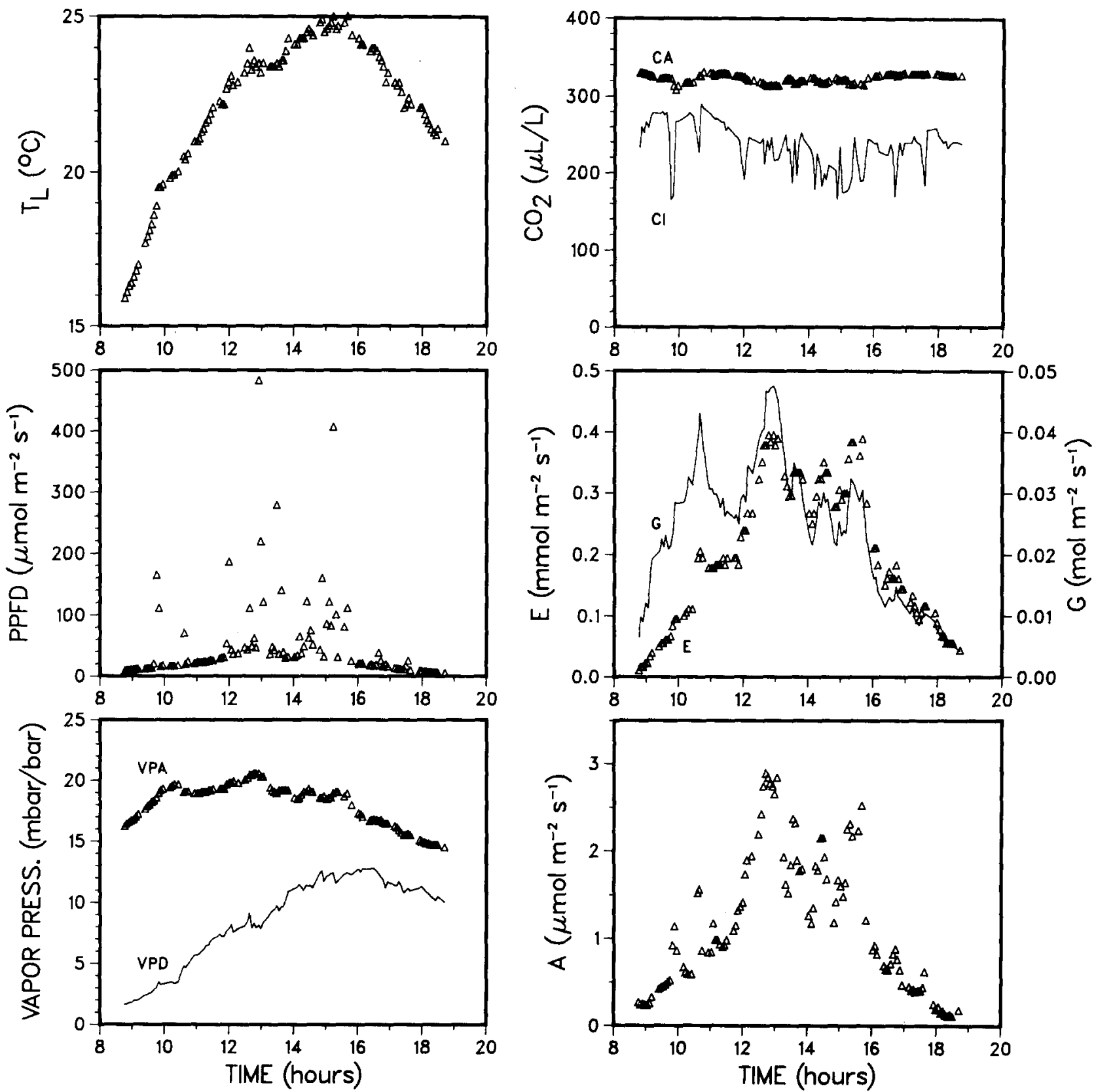

Fig. 5. Diurnal course of photosynthesis $A$, transpiration $E$, leaf conductance to water vapor $G$, and environmental factors for 13 Sept 1981

fitting the data to Eq. (2) with non-linear regression techniques, variation in PPFD alone can account for $70 \%$ of the variation in $A$ (Fig. 6).

On both days, 15 distinct peaks in PPFD occur. Associated with these peaks are maxima in $A$ although the maxima in $A$ are delayed by 5 to $10 \mathrm{~min}$. The lag in the response is caused by the low flow rate though the system. In addition the maxima in $A$ are much broader (extended over a much longer period) for two reasons. First, the low flow rate and large volume of the chamber increases mixing time of the gas in the chamber. Second, the sensing area of the quantum sensor and the area of the leaf did not coincide and were of different sizes $\left(0.78 \mathrm{~cm}^{2}\right.$ and $30-50 \mathrm{~cm}^{2}$, respectively) so that there may have been a difference between actual incident on the leaf and measured PPFD.

The apparent quantum efficiency for incident PPFD at normal $\mathrm{CO}_{2}$ and $\mathrm{O}_{2}$ concentrations ( $\alpha$ (atm)), $A$ divided by incident PPFD estimated for each measurement point obtained at low PPFD (diffuse light below $50 \mu \mathrm{mol}$ $\mathrm{m}^{-2} \mathrm{~s}^{-1}$ ), was about $0.04 \mathrm{~mol} \mathrm{CO} 2 / \mathrm{mol}$ quanta. Comparing this apparent quantum efficiency with that obtained from light response curves (Table $1 \mathrm{~A}$ ), it is evident that the leaves were operating at near maximum quantum efficiency for the $\mathrm{CO}_{2}$ and $\mathrm{O}_{2}$ concentrations experienced in the field. More than $75 \%$ of the time PPFD remains at less than $50 \mu \mathrm{mol} \mathrm{m} \mathrm{m}^{-2} \mathrm{~s}^{-1}$, and during these periods $60 \%$ of the total $\mathrm{CO}_{2}$ fixation takes place (Table 3). At PPFD greater than $50 \mu \mathrm{mol} \mathrm{m} \mathrm{m}^{-2} \mathrm{~s}^{-1}$ the apparent quantum efficiency, calculated as $A$ divided by $I$, decreased as expected.

Stomatal conductance $(G)$ was positively correlated with PPFD, $T_{l}$, and VPA; and negatively with VPD and $C_{a}$ (Table 2). Statistical selection methods indicated that $90 \%$ 
Table 2. Correlation table for photosynthesis and conductance with environmental factors using data from the daily time course measurements

\begin{tabular}{|c|c|c|c|c|}
\hline \multirow{2}{*}{$\begin{array}{l}\text { Environ- } \\
\text { mental } \\
\text { factors }\end{array}$} & \multicolumn{2}{|l|}{ A } & \multicolumn{2}{|l|}{$\mathrm{G}$} \\
\hline & 12 Sept. & 13 Sept. & $12 \mathrm{Sept}$ & 13 Sept. \\
\hline$T_{1}$ & $0.77 * *$ & $0.59 * *$ & $0.78 * *$ & $0.25 * *$ \\
\hline VPA & $0.92 * *$ & $0.78 * *$ & $0.98 * *$ & $0.94^{* *}$ \\
\hline VPD & 0.17 & $0.24 *$ & 0.11 & $-0.20^{*}$ \\
\hline I & $0.71 * *$ & $0.54 * *$ & $0.59 * *$ & $0.42^{* *}$ \\
\hline $\mathrm{C}_{\mathrm{a}}$ & $-0.96 * *$ & $-0.75^{* *}$ & $-0.93 * *$ & $-0.68 * *$ \\
\hline $\mathrm{G}$ & $0.94 * *$ & $0.84 * *$ & - & - \\
\hline $\mathrm{N}$ & 51 & 89 & 51 & 89 \\
\hline
\end{tabular}

* Significant at $P=0.05$

** Significant at $P=0.01$

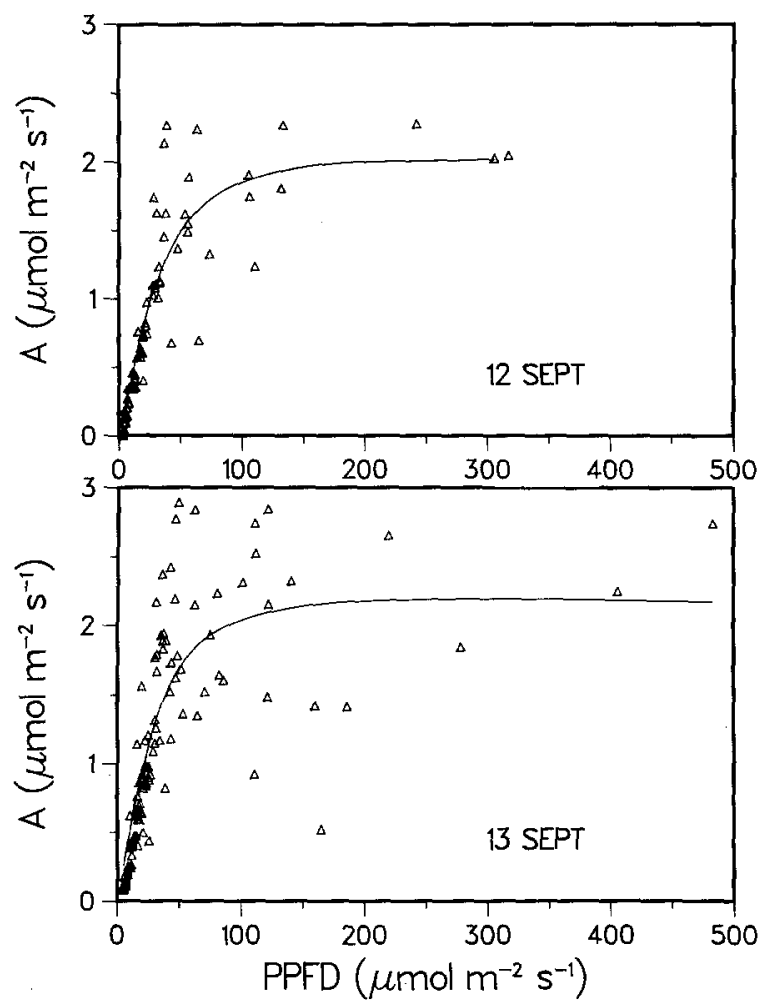

Fig. 6. Photosynthesis rates of daily time course data plotted as a function of $P P F D$. Solid line in each Fig is the regression line for Eq. (2). A. $A_{\mathrm{M}}(\mathrm{atm})=2.04 \mu \mathrm{mol} \mathrm{m} \mathrm{m}^{-2} \mathrm{~s}^{-1} . \alpha(\mathrm{atm})=0.0442$ $\mathrm{mol} / \mathrm{mol}$. B. $A^{\mathrm{M}}(\mathrm{atm})=2.22 \mu \mathrm{mol} \mathrm{m} \mathrm{m}^{-2} \mathrm{~s}^{-1} . \alpha(\mathrm{atm})=0.0519 \mathrm{~mol} /$ $\mathrm{mol}$

of the variation in stomatal conductance could be accounted for by a multiple linear regression on $T_{l}, C_{a}$, and VPD. Ball and Berry (1982) have proposed that stomatal conductance is regulated such that the ratio $C_{i} / C_{s}$, where $C_{s}$ is the $\mathrm{CO}_{2}$ concentration at the leaf surface, is maintained constant. Since all measurements were made at constant wind velocity, and therefore constant boundary layer conductance, the ratio $C_{i} / C_{a}$ should also be constant. There is a general tendency for this ratio to be between 0.7 and 0.8 (Fig. 7). This value is approached slowly during the morning and is disturbed during sunflecks.

At low PPFD the transpiration ratio $(E / A)$ is approximately $200 \mathrm{~mol} \mathrm{H}_{2} \mathrm{O} / \mathrm{mol} \mathrm{CO}$ (Fig. 8). At higher PPFD
Table 3. Analysis of the photosynthetic response during daily time course on 13 September 1981 according to PPFD categories. Numbers in parentheses are percentages of total

\begin{tabular}{|c|c|c|c|c|c|}
\hline \multirow[b]{2}{*}{$\vdots$} & \multicolumn{5}{|c|}{ PPFD category $\left(\mu \mathrm{mol} \mathrm{m}{ }^{-2} \mathrm{~s}^{-1}\right)$} \\
\hline & $0-25$ & $26-50$ & $51-75$ & $76-100$ & $>100$ \\
\hline $\begin{array}{l}\text { Photon flux } \\
\mathrm{mol} / \mathrm{m}^{2} \\
\%\end{array}$ & $\begin{array}{c}0.262 \\
(16.0)\end{array}$ & $\begin{array}{c}0.379 \\
(23.1)\end{array}$ & $\begin{array}{l}0.118 \\
(7.2)\end{array}$ & $\begin{array}{l}0.120 \\
(7.3)\end{array}$ & $\begin{array}{c}0.761 \\
(46.4)\end{array}$ \\
\hline $\begin{array}{c}\text { Measured A } \\
\text { mmol/m } \mathrm{m}^{2} \\
\%\end{array}$ & $\begin{array}{r}9.67 \\
(23.8)\end{array}$ & $\begin{array}{c}16.82 \\
(41.2)\end{array}$ & $\begin{array}{c}3.30 \\
(8.1)\end{array}$ & $\begin{array}{c}2.90 \\
(7.1)\end{array}$ & $\begin{array}{r}8.02 \\
(19.7)\end{array}$ \\
\hline $\begin{array}{l}\text { Simulated A } \\
\mathrm{mmol} / \mathrm{m}^{2} \\
\%\end{array}$ & $\begin{array}{c}11.41 \\
(27.3)\end{array}$ & $\begin{array}{c}15.23 \\
(35.1)\end{array}$ & $\begin{array}{c}4.12 \\
(9.5)\end{array}$ & $\begin{array}{c}3.16 \\
(7.3)\end{array}$ & $\begin{array}{r}9.51 \\
(21.9)\end{array}$ \\
\hline $\begin{array}{l}\text { Time } \\
\text { sec } \\
\%\end{array}$ & $\begin{array}{l}17,856 \\
(48.9)\end{array}$ & $\begin{array}{c}10,548 \\
(29.5)\end{array}$ & $\begin{array}{l}1,872 \\
(5.2)\end{array}$ & $\begin{array}{l}1,476 \\
(4.1)\end{array}$ & $\begin{array}{c}3,996 \\
(11.2)\end{array}$ \\
\hline $\begin{array}{r}\text { Measured } \\
\alpha(\mathrm{atm})\end{array}$ & 0.037 & 0.044 & 0.028 & 0.024 & 0.011 \\
\hline $\begin{array}{c}\text { Simulated } \\
\alpha(\mathrm{atm})\end{array}$ & 0.044 & 0.040 & 0.035 & 0.026 & 0.012 \\
\hline
\end{tabular}
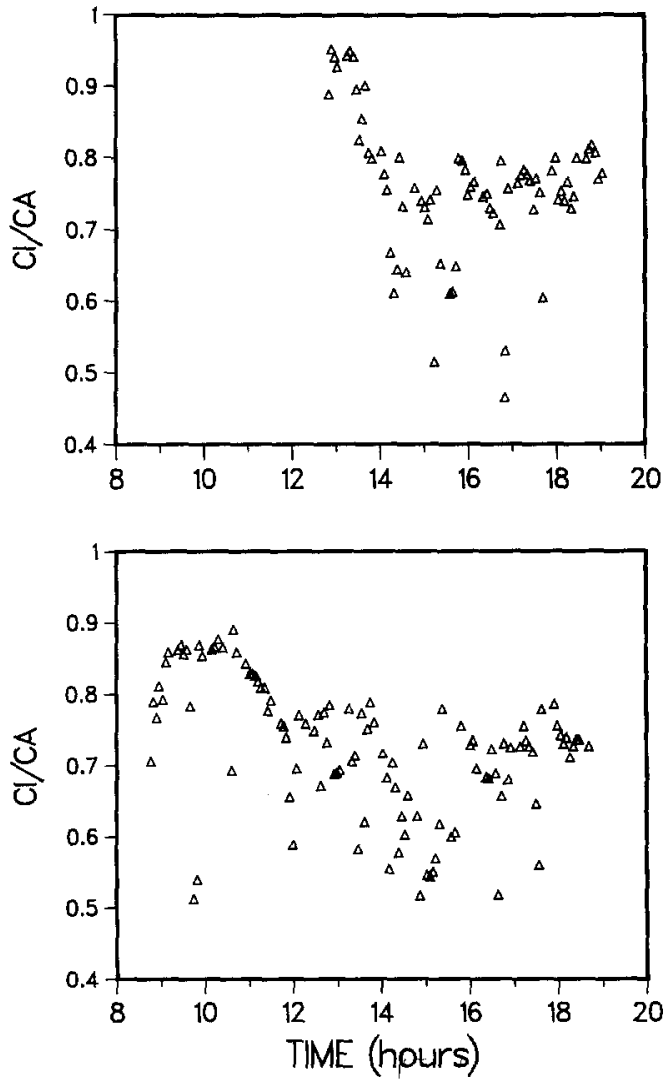

Fig. 7. Variation of $C_{i} / C_{a}$ throughout the day. Top: 12 September. Bottom: 13 September

the leaves use water more effectively and $E / A$ declines to approximately 140 . In part this effective water use may result from sluggish reaction of stomata to increased PPFD during sunflecks, whereas $A$ increases quickly and draws $C_{i}$ down (Fig. 7). There is a strong correlation between $A$ and $G$ (Fig. 8), except for data obtained during the early 

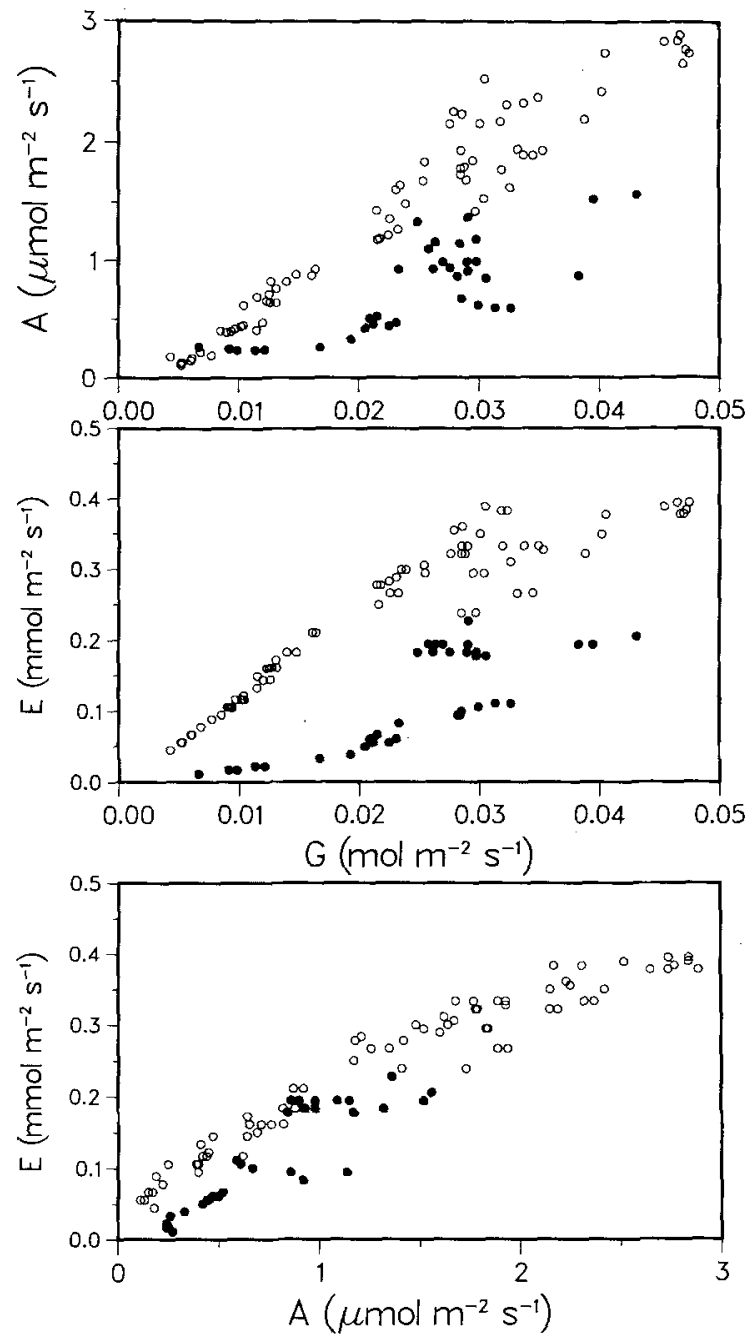

Fig. 8. Relationship of leaf conductance $G$ to transpiration $E$, top, and photosynthesis $A$, middle. Relationship between transpiration $E$ and photosynthesis $A$, bottom. Daily time course data for 13 September 1981. Solid symbols represent data taken in the morning

morning period. During the early morning when VPA is high, stomata open rapidly and photosynthesis increases relatively slowly due to low $T_{l}$ and low PPFD. In the afternoon, when VPA is lower and VPD is substantial, water use is more effectively regulated. In this situation, $G$ and $A$ decrease simultaneously.

Integrating over $24 \mathrm{~h}$ periods, we obtain a net carbon gain of $32.1 \mathrm{~m} \mathrm{~mol} \mathrm{~m}-2$ on 12 September and $38.9 \mathrm{~m}$ $\mathrm{mol} \mathrm{m} \mathrm{m}^{-2}$ on 13 September, an average of $35.5 \mathrm{~m} \mathrm{~mol} \mathrm{~m} \mathrm{~m}^{-2}$. If this average carbon gain occurs over a 120 day growing season, the estimated total carbon gain for the season would be $4.3 \mathrm{~mol} \mathrm{CO}_{2} \mathrm{~m}^{-2}$ or $0.72 \mathrm{~mol}$ glucose $\mathrm{m}^{-2}$. Maintenance respiration costs of leaves are included in this estimate. An estimate of the amount of glucose needed to produce new leaves in the following growing season may be obtained by multiplying specific leaf weight $\left(25-30 \mathrm{~g} \mathrm{~m}^{-2}\right)$ by the conversion factor for synthesis of leaf material from glucose determined by Penning de Vries $(1974 ; 1.5 \mathrm{~g}$ glucose/g tissue). It is assumed that $\mathrm{NO}_{3}^{-}$and $\mathrm{SO}_{4}^{-}$are the sources of nitrogen and sulfur. We calculate that $0.2-0.23 \mathrm{~mol}$ glucose are required to produce $1 \mathrm{~m}^{2}$ leaf, which is approximately $30 \%$ of the carbon gained.
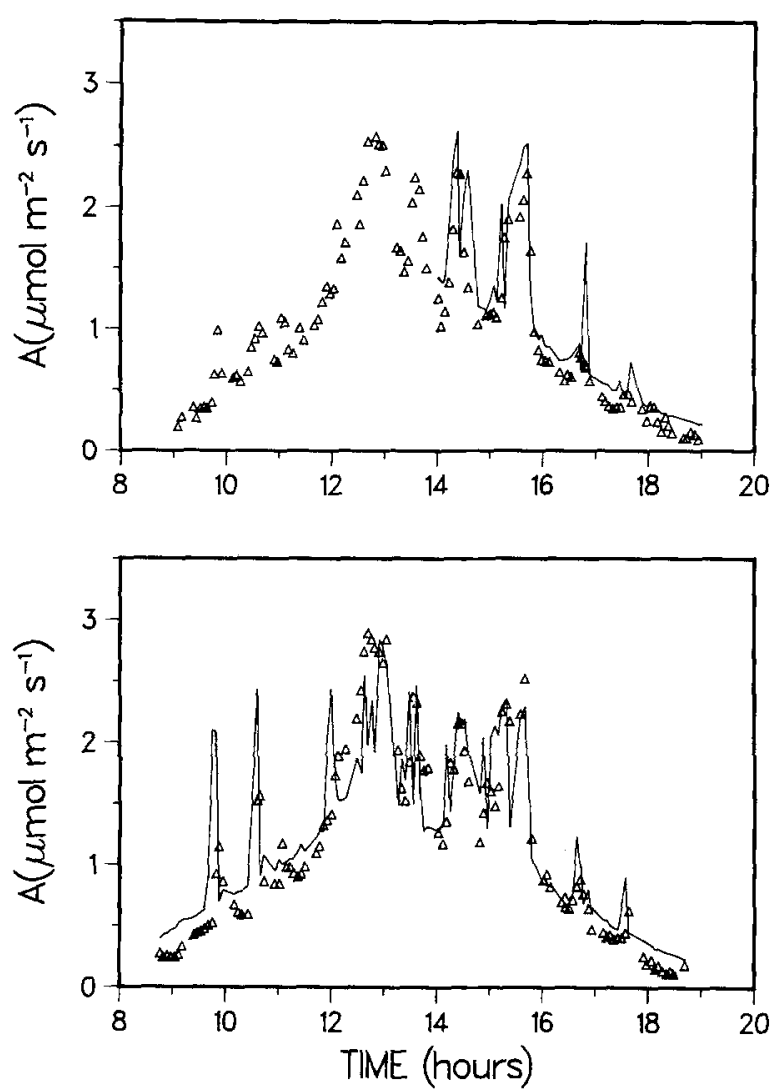

Fig. 9. Comparison of measured (symbols) and simulated (solid line) daily time course of photosynthesis for $12 \mathrm{Sept}$ (top) and 13 Sept (bottom). Parameter values in Table $1 \mathrm{~B}$ and C

\section{Simulation of the time course of $A$}

Equation (4) and parameter values given in Table 1 were used to simulate the measured A (Fig. 9). We do not test extensively the model or describe detailed applications. The purpose here is to demonstrate how laboratory determination of parameters may be related meaningfully to the leaf response under fluctuating environmental conditions, to examine whether such a model reproduces the general behavior of the leaves, and to identify problems specific to modeling of gas exchange in the shade environment of the forest floor. More detailed studies with the model, including examination of water use efficiency, will be described later.

Equation (4) was used to calculate a simulated value for net $\mathrm{CO}_{2}$ exchange $(F)$ at each point where valid measurements had been obtained for PPFD, $T_{l}, C_{a}$, and $G$. The parameters $P_{m}$ and $R_{d}$ were considered to vary with $T_{l}$ according to the Arrhenius equation; $\Gamma^{*}$ varied with $T_{l}$ over the temperature of interest (Table 1). The parameter $\mathrm{CE}$ was treated as as function of PPFD

$\mathrm{CE}=\min \quad\left\{\begin{array}{l}I \cdot 0.0003 \\ \mathrm{CEM}\end{array}\right.$

where: CEM is the PPFD-saturated carboxylation efficiency, and min $\{$ means the minimum value is chosen.

The increase in CE with $I$ at low PPFD $(0.0003 \mu \mathrm{mol}$ $\mathrm{CO}_{2} /(\mu \mathrm{1} / 1) / \mu \mathrm{mol}$ quanta) was estimated from several data sets similar to that shown in Fig. 2. Equation (5) was used because preliminary data indicate that $\mathrm{CE}$ as measured here rises rapidly with increasing PPFD then rapidly saturates. The value for $\alpha$ was held constant at $0.06 \mathrm{~mol} \mathrm{CO}_{2} / \mathrm{mol}$ 
quanta. Internal $\mathrm{CO}_{2}$ concentration, $C_{i}$, was obtained iteratively.

The general pattern of $F$ is similar to $A$ but the simulation is characterized by a series of extremely sharp peaks where measurements indicate broad ones (Fig. 9). Rapid light fluctuations cause overestimation and underestimation of the measured chamber rate by the calculated rate because mixing in the chamber tends to dampen the oscillations in $A$ produced by rapid changes in PPFD. Integrated $F$ is $107 \%$ of integrated $A$ for 13 September, and $122 \%$ of the portion of the day simulated for 12 September.

\section{Discussion}

The results obtained in this study are in many ways similar to those obtained by Björkman et al. (1972) with Alocasia macrorrhiza and Cordyline rubra growing on the floor of a rainforest in Queensland, Australia and by Pearcy and Calkin (1983) with Claoxylon sandwicense in Hawaii. In contrast, however, direct and diffuse radiation fluxes were approximately one order of magnitude greater on the floor of this mixed hardwood forest. In addition greater change in $C_{a}$ and VPA occurred. Compared to the rainforest species, Acer saccharum had a specific leaf weight approximately the same, $A_{m}(\mathrm{~atm})$ was about the same, average $A$ during the day was about 3 times greater, and apparent maximum quantum efficiency $\alpha(\mathrm{atm})$ was lower $(0.04 \mathrm{~mol} / \mathrm{mol} \mathrm{com}$ pared to 0.05 for C. sandwicense and 0.07 for A. macrorrhiza). As in the studies of Björkman et al. (1972) and Pearcy and Calkin (1983) the pattern observed in the daily time course of $A$ was primarily determined by available PPFD. Stomata were seen to respond to large changes in PPFD during sunflecks but much less than did photosynthesis.

Approximately $45-55 \%$ of the total photon flux occurred during periods of high PPFD $\left(>100 \mu \mathrm{mol} \mathrm{m}^{-2} \mathrm{~s}^{-1}\right)$, while $35-40 \%$ occurred during the low PPFD ( $>50 \mu \mathrm{mol}$ $\mathrm{m}^{-2} \mathrm{~s}^{-1}$ ) periods (Table 3). Net carbon gain during high PPFD was $20-30 \%$ of the total, whereas $55-65 \%$ of the carbon was fixed during low PPFD. While it seems clear that sunflecks provide an important contribution to productivity of maple seedlings on the forest floor as has been concluded in other studies (Björkman et al. 1972; Young and Smith 1983), it is necessary to compare the photosynthate accumulated with and without the additional input from sunflecks. To this end we calculated the net $\mathrm{CO}_{2} \mathrm{ex}-$ change assuming that PPFD's for the high PPFD period were in the range indicated in category 2 or 3 (Table 3 ). With only diffuse light (PPFD $<50 \mu \mathrm{mol} \mathrm{m}^{-2} \mathrm{~s}^{-1}$ ) the reduction in net $\mathrm{CO}_{2}$ fixation is about $5 \%$. Estimates using the model are a reduction of $12 \%$ at most. A similar estimate for the data on $A$ of $A$. macrorrhiza obtained by Björkman et al. (1972) suggests that total carbon gain would be reduced by $10 \%$ if there were no sunflecks. This result is apparently caused coincidentally by differences in length of time spent at various PPFD's and by the low PPFD required to saturate photosynthesis in A. saccharum. With similar lengths of time during sunflecks $A$. macrorrhiza would be expected to utilize the period more efficiently than $A$. saccharum because $A$. macrorrhiza has 1) a greater quantum efficiency, and 2) a greater stomatal conductance.

In spite of significant problems confronted in assessing average PPFD (see also Pearcy 1983) it was possible to simulate mathematically $A$ as a function of PPFD, $T_{l}, G$, and $C_{a}$. Parameter estimates were obtained from single fac- tor response curves in the laboratory and in the field. Favorable comparison of $F$ with $A$ suggests that the approach taken here should be further pursued in order to develop methods which will aid in linking laboratory studies to response under natural conditions. The importance of the interaction between $\mathrm{CO}_{2}$ and PPFD is indicated by the decrease in CE, assessed between 80 and $160 \mu \mathrm{l} / 1 C_{i}$, with decreasing PPFD (Fig. 2). While previous studies have shown the interaction (Ludlow and Wilson 1971; Ku et al. 1977), relatively little work has been directed toward accurately describing this interaction. A dependency of CE on PPFD is an absolutely essential component of any mathematical model intended to simulate gas exchange of $A$. saccharum shade leaves. Further experimentation suggests that the same conclusion may be drawn for any leaves growing under shade conditions, and it appears to us that correct description of the PPFD dependency of CE will be extremely important in description of canopy function. While CE is a function of $C_{i}$ at which its value is estimated, at least in $A$. saccharum we feel that $C E$ is influenced as well by actual metabolic components. As PPFD decreases, RuBP production decreases, leading to decreased steady-state levels (Collatz 1972; Sharkey 1983; Jensen et al. 1983). The activation state of RuBP carboxylase also changes, with less activation occurring at low PPFD (Perchorowicz et al. 1981; Jensen et al. 1983). Either change could be involved in the dependence of CE on PPFD.

During the growing season, the potential rates of carbon fixation of $A$. saccharum leaves remain quite constant. It appears relatively safe to make an initial estimate of the total seasonal carbon gain by the methods indicated in the results section. We conclude that after supplying maintenance respiration and reserving adequate carbon to reconstruct new leaves during the following growing season, A. saccharum leaves provide substantial amounts of carbon for maintenance respiration of stems and roots and for storage ( $70 \%$ of seasonal fixation). Further studies are planned to examine the ways in which this carbon pool is utilized over the annual cycle.

Acknowledgements. We wish to thank Ikchul B. Um and E. Raymond Hunt for assistance in the laboratory studies and Jeffrey Axelrod for assistance in the field studies. This research was supported by contracts (DE-ACO2-76EY02164 and DE-ACO279EX10091) from the U.S. Department of Energy to DMG.

\section{References}

Ball JT, Berry JA (1982) The $C_{i} / C_{s}$ ratio: a basis for predicting stomatal control of photosynthesis. Carnegie Inst. Yr Bk $81: 88-92$

Björkman O (1968) Further studies on differentiation of photosynthetic properties in sun and shade ecotypes of Solidago virgaurea. Physiol Plant 21:84-99

Björkman O, Ludlow MM (1972) Characterization of the light climate on the floor of a Queensland rainforest. Carnegie Inst Yr Bk 71:85-94

Björkman O, Ludlow MM, Morrow PA (1972) Photosynthetic performance of two rainforest species. Carnegie Inst. Yr Bk $71: 95-102$

Bloom AJ, Mooney HA, Björkman O, Berry JA (1980) Materials and methods for carbon dioxide and water exchange analysis. Plant Cell Environ 3:371-376

Boardman NK (1977) Comparative photosynthesis of sun and shade plants. Ann Rev Plant Physiol 28:355-377

Collatz JG (1978) The interaction between photosynthesis and ri- 
bulose $\mathrm{P}_{2}$ concentration - effects of light, $\mathrm{CO}_{2}$, and $\mathrm{O}_{2}$. Carnegie Inst. Yr Bk 77:248-251

Curtis JT (1959) The vegetation of Wisconsin: an ordination of plant communities. University of Wisconsin Press, Madison

Dixon W (1969) BMD biomedical computer programs X-series supplement. Berkeley-Los Angeles: University of California Press

Hett JM, Loucks OL (1971) Sugar maple (Acer saccharum Marsh.) seedling mortality. J Ecol 59:507-520

Jensen RG, Mott KA, Raynes DA, Perchorwicz JT (1983) Role of the acclimation status of ribulose 1,5-bisphosphate carboxylase in regulating photosynthesis. In: Sybesma $\mathrm{C}(\mathrm{ed})$, Martinus Nijhoff/Dr. W Junk (publ). Advances in Photosynthesis Research. The Hague. Vol. III, pp 735-738

Johnson F, Eyring H, Polissar M (1954) The kinetic basis of molecular biology. J Wiley New York

Jurik TW, Weber JA, Gates DM (1984) Short-term effects of $\mathrm{CO}_{2}$ on gas exchange of field leaves of bigtooth aspen (Populus grandidentata). Plant Physiol 75:1022-1027

Koch W, Lange OL, Schulze E-D (1971) Ecophysiological investigation on wild and cultivated plants in the Negev Desert. I. Methods: A mobil laboratory for measuring carbon dioxide and water exchange. Oecologia (Berlin) 8:296-309

Ku S-B, Edwards GE, Tanner CB (1977) Effects of light, carbon dioxide, and temperature on photosynthesis, oxygen inhibition of photosynthesis, and transpiration in Solanum tuberosum. Plant Physiol 59:868-872

Lange OL, Schulze, E-D, Koch W (1967) Experimentell-ökologische Untersuchungen an Flechten der Negev-Wüste. II. $\mathrm{CO}_{2}-$ Gaswechsel und Wasserhaushalt von Ramalina maciformis (Del.) Bory am natürlichen Standort während der sommerlichen Trockenperiode. Flora 159:38-62

Larcher W (1980) Ökologie der Pflanzen. Ulmer Stuttgart

Ledig FT, Korbobo DR (1983) Adaptation of sugar maple populations along altitudinal gradients: photosynthesis, respiration, and specific leaf weight. Am J Bot 70:256-265

Leverenz JW, Jarvis PG (1980) Photosynthesis in Sitka spruce (Picea sitchensis (bong.) Carr.). X. Acclimation to quantum flux density within and between trees. J Appl Ecol 17:697-708

Logan KT, Krotkov G (1968) Adaptations of the photosynthetic mechanism of sugar maple (Acer saccharum) seedlings grown in various light intensities. Physiol Plant 22:104-116

Ludlow MM, Wilson GL (1971) Photosynthesis of tropical pasture plants. 1. Illuminance, carbon dioxide concentration, leaf temperature, and leaf air vapor pressure difference. Aust J Biol Sci 24:449--470
Malkina IS, Celniker JL, Jaksina AM (1970) Fotosintez i dychanie podrosta. Nauka, Moskau

McMillan GG, McClendon JH (1983) Dependence of photosynthetic rates on leaf density thickness in deciduous woody plants grown in sun and shade. Plant Physiol 72:674-678

Pearcy RW (1983) The light environment and growth of $\mathrm{C}_{3}$ and $\mathrm{C}_{4}$ species in the understory of a Hawaiian forest. Oecologia (Berlin) 58:19-25

Pearcy RW, Calkin HW (1983) Carbon dioxide exchange of $\mathrm{C}_{3}$ and $\mathrm{C}_{4}$ tree species in the understory of a Hawaiian forest. Oecologia (Berlin) 58:26-32

Penning de Vries FWT, Brunsting AHM, van Laar HH (1974) Products, requirements, and efficiency of biosynthesis : A quantitative approach. J Theor Biol 45:339-377

Perchorowicz JT, Raynes DA, Jensen RG (1981) Light limitation of photosynthesis and activation of ribulose bisphosphate carboxylase in wheat seedlings P.N.A.S. 78:2985-2989

Sharkey TD, Badger MR, von Caemmerer S (1983) Factors limiting photosynthesis as determined from gas exchange characteristics and metabolite pools sizes. In: Sybesma C (ed), Martinus Nijhoff/Dr. W Junk (publ). Advances in Photosynthesis Research. The Hague. Vol. IV, pp 325-328

Smith EL (1937) The influence of light and carbon dioxide on photosynthesis. J General Physiol 20:807-830

Smith EL (1938) Limiting factors in photosynthesis: Light and carbon dioxide. J General Physiol 21:21-35

Spurr SF, Barnes B (1980) Forest Ecology. Wiley, New York

Tenhunen JD, Weber JA, Yocum CS, Gates DM (1976) Development of a photosynthesis model with an emphasis on ecological applications. II. Analysis of a data set describing the $\mathbf{P}_{\mathbf{M}}$ surface. Oecologia (Berlin) 26:101-119

Tenhunen JD, Meyer A, Lange OL, Gates DM (1980) Development of a photosynthesis model with an emphasis on ecological applications. V. Test of the applicability of a steady-state model to description of net photosynthesis of Prunus armeniaca under field conditions. Oecologia 45:147-155

Young DR, Smith WK (1983) Effects of cloudcover on photosynthesis and transpiration in the subalpine understory species $\mathrm{Ar}$ nica latifolia. Ecology 64:681-687

Wong SC, Cowan IR, Farquhar GD (1979) Stomatal conductance correlates with photosynthetic capacity. Nature 282:424-426

Received May 25, 1984 